\title{
COLLABORATIVE FUTURES
}

\section{Arts Funding and Speculative Fictions}

In the United States of America, public funding for the arts is under threat. In March of 2019, the Trump administration released its proposed 2020 federal budget calling for an end to arts funding through the National Endowment for the Arts (NEA): "The Budget proposes to begin shutting down NEA in 2020 and it would provide sufficient funding for orderly termination of all operations over two years. The Administration does not consider NEA activities to be core Federal responsibilities" (A Budget 98). The proposal went on to encourage privatization by pointing out that the transition to funding the arts through the market was already well underway:

Giving to the arts by individuals, foundations, and corporations grew 7.0 percent to $\$ 17.07$ billion in 2015-representing 4.6 percent of all charitable giving and the fourth consecutive year of growth. Additionally, technology has broadened the reach of support for the arts. For example, one internet platform, Kickstarter, reported that it connected donors and artists to fund over $\$ 300$ million arts-related projects. The Administration believes audiences and aficionados are better than the Government at deciding what art is good or important. (A Budget 98).

Framed as a tech-savvy arts institution by the Trump Administration, Kickstarter's mention in the budget invites us to consider how its corporate model of privatized arts patronage has penetrated contemporary art forms. To think through how the public benefit

J.D. Schnepf University of Groningen The Netherlands

(iD 
corporation founded in 2009 functions as an artistic institution, we might begin with the following questions: How has Kickstarter's crowdfunding model shaped certain forms of artistic production and foreclosed others? How have the arts imagined and even incorporated the aesthetics engendered through crowdfunding? To address these questions, I turn to a case that highlights Kickstarter's unlikely role in the transmedial and international collaboration between US science fiction writer, Kim Stanley Robinson, and Serbian performance artist, Marina Abramović. To procure funding for the first phase of a proposed institution for the performing arts in Hudson, New York, Abramović posted her plans for the Marina Abramović Institute (MAI) on Kickstarter in 2013. Pledges received via Kickstarter in this initial phase of fundraising went toward the institute's design: specifically, "to early MAl programming, office operations, and schematic designs of architectural elements, including building structure, lighting, acoustics, and AV" ("Marina Abramović Institute"). Four years later, Robinson set a scene of his 2017 speculative fiction, New York 2140, at the Marina Abramović Institute. We will turn to the actual fate of the Institute momentarily but to begin, let us consider its fate in Robinson's novel.

In New York 2140, climate change has remade the planet's ecosystems: animal habitats and ice sheets have dissipated, New York City has suffered not one but two "pulses"-rapid rises in sea level that plunge everything once at ground-level well underwater.

One World The Americas Everywhere The persistence of global finance under these conditions means that some citizens profit off of environmental devastation while those without resources die or struggle to survive. In this context of climate disaster, Robinson unfolds a minor subplot that follows the novel's resident animal conservationist and nature show host, Amelia Black. As a massive hurricane barrels toward New York City, Amelia finds the storm's wind gusts too strong to return to her home in Manhattan's MetLife building. Instead of battling her way through the storm she decides to outrun it in her trusty airship, the Assisted Migration. Buttressed by a strong tailwind, Amelia and her ship make their way north, alighting on the town of Hudson, New York, where she takes refuge on the grounds of the "Marina Abramović Institute" (Robinson 521). Anchored 
to the ground, her airship's "intense flailing became a natural piece of performance art, and at first Amelia had resolved to stay in the gondola through the hurricane-tie herself into a chair and get tossed around like a bull rider, like Marina herself doing one of her variously dangerous and awesome performances [...]" (Robinson 521). Despite her initial desire to make performance art out of the disaster, the Institute's kindly curators convince Amelia to relent and shelter from the hurricane indoors.

Compared to an earlier journey to Antarctica to relocate a pack of polar bears, Amelia's excursion up the Hudson River Valley seems like an altogether forgettable affair. And yet, the brevity of Amelia's sojourn to the Marina Abramović Institute belies the significance of its appearance in the text. The actual fate of the Marina Abramovic Institute for the Preservation of Performance Art-or the MAl as it was affectionately referred to by Abramović-is that it never came to be. While Abramović's plan to construct a brick-and-mortar institution ultimately went unrealized, the speculation fostered by Kickstarter's crowdfunding platform summoned a host of artists to imagine details and narratives about the Institute that would later appear in Robinson's novel. By attending to the MAl's fictional presence in text, we can see how Robinson's novel engages with corporate crowdfunding for the arts as both a conceptual resource and a catalyst of speculative storytelling. But perhaps more significantly, this detail also suggests that the crowdfunding model of arts patronage requires us to reexamine the aesthetic terms that artists and critics alike have come to rely on in order to differentiate science fiction from other kinds of writing. For example, Robinson has argued that:

The way you distinguish science fiction from fantasy is that it's a historical literature. A science fiction novel will be placed in a future of ours, and you can run a track from this moment to that moment that's a history. It's either explicit in the text or it's implicit, and you have to play a game of figuring out what happened to get from here to there. So science fiction properly conceived-which is really just my own way of conceiving it, of course-is a historical literature. (Heise 24-25)

In her account of New York 2140's evocation of capitalist realism, literary scholar Anna Kornbluh also draws attention to what she sees as the novel's temporal continuity from our 
moment to a plausible future. Kornbluh bases her reading in part on the novel's insistence on the endurance of Manhattan's Met Life Tower-"a regular, actually existing skyscraper of an actually existing insurance company" (Kornbluh 2019-2020: 108). She argues that featuring the building in the story's setting testifies to "how little has changed from the time of [the novel's] publication in 2017 to the time of setting in 2140" (109). Indeed, according to Kornbluh, "[i]n dwelling on the infrastructure of old buildings and ordinary construction, New York 2140 anchors its floating future in the current present of practicable maintenance" which gives the effect of an "immersive continuity between future and present [...]" (109). Moreover, she suggests that "architectural details hewing to the space-time continuum differentiate realism from science fiction and effectuate realism's trademark infrastructural, institutional concerns" (109). But if a reader were to attend to the Maria Abramović Institute instead of the Met Life Tower she would find that the novel's buildings do not consistently confirm a continuity between present and future. In fact, the very presence of the brick-and-mortar MAl in the world of 2140 challenges interpretations that seek to identify the work as a realist or a historical fiction without accounting for the broken continuity betrayed by this imaginary structure.

One World

The Americas

Everywhere

The artistic collaboration between Abramović and Robinson began under the auspices of a speculative arts institution with a more conventional system of financial patronage. In the winter of 2015, the two were named artists-in-residence at the Arthur C. Clarke Center for Human Imagination at the University of California, San Diego. The Clarke Center's stated objective is to "understand, enhance, and enact the gift of human imagination by bringing together the inventive power of science and technology, with the critical analysis of the humanities, and the expressive insights of the arts" (Imagination). Although Robinson made reference to Abramović in his 2012 Nebula award-winning novel, 2312, the 2015 Clarke residency marked the first time the novelist and the performance artist worked in unison. Together, the two artists produced a series of multimedia works that brought Robinson's interest in the vast distances and durations of space travel together with 
Abramovićs desire to retool the public perception of everyday space and time. Their collaboration yielded "an installation with multiple audio tracks" that appeared first in the University's Art Gallery and later as an exhibit at the Venice Biennale, a theatrical podcast called, "The Hard Problem: An Audio Voyage,"” and a short film entitled, 3015. Robinson wrote New York 2140 from roughly 2014 to early 2017 and thus his residency at the Arthur C. Clarke Center alongside Abramović coincides with his writing of the sprawling speculative tome.

The Clarke Center is named after Arthur C. Clarke, a popular midcentury intellectual and a self-described, "engineer, futurist, and humanist" whose eponymous foundation furnishes a portion of the Center's funding ("Arthur C. Clarke. Biography"). In the 1940s, Clarke speculated that a system of global telecommunication might be achieved by launching satellites into geostationary orbits. Later, as a writer of science fiction, Clarke would produce dozens of stories and co-write the screenplay for 1968's 2001: A Space Odyssey with filmmaker Stanley Kubrick ("Arthur C. Clarke. Biography"). As a US literary institution, the Arthur C. Clarke Center's significance cannot be overstated: indeed, UC San Diego touts itself as a "Leading Public University with the most alumni to go on to be professional writers of speculative fiction" ("About Clarion"). According to the Center's director, Sheldon Brown, "we have produced more of today's notable science fiction writers than any other university in the world" (Imagination). Brown's claim depends on the Center's recent acquisition of the Clarion Science Fiction and Fantasy Writers' Workshop-"the oldest workshop of its kind and [...] widely recognized as a premier proving and training ground for aspiring writers of fantasy and science fiction."2 Esteemed alumni include Octavia Butler, Ted Chiang, and-not surprisingly-Kim Stanley Robinson. ${ }^{3}$ Founded at Clarion State College in Pennsylvania in 1968, and relocated to Michigan State University for thirty-four years, the Clarke Center has assumed the mantle of "host and coordinator of the Clarion Workshop since 2012" ("About Clarion"). This move

1. See "Episode 3: The Hard Problem."

2. See "The Clarion Science Fiction and Fantasy Writer's Workshop."

3. See "Clarion Distinguished Alumni \& Faculty." 
placed the Clarion Workshop under the Clarke Center's formidable institutional wing.

The Arthur C. Clarke Center is well financed owing to a steady flow of public and private donations. In its efforts to court public gifts, the Center reminds visitors that its "growth depends on research grants, alliances, strategic partnerships and the support of an interested public. Support can take many forms: from participation in our many public programs to partnerships to contributions" (Imagination). Its biggest private donor is ViaSat Incorporated. Described as a "founding partner" of the Center, the multinational communications company and defense contractor spells out on its website that its broad corporate mission is to "shape how consumers, businesses, governments and militaries around the world communicate" ("About ViaSat"). Among other things, this capacity to alter military communications means "giv[ing] all combatants greater situational awareness in any battle space by collecting information and combining it into a digital view of the battlefield" ("About ViaSat"). For example, ViaSat is responsible for "supply[ing] digital video links for unmanned systems (UAS) that increase the range, security, and effectiveness of UAVs as they become a greater part of military strategy" ("About ViaSat").

One World

The Americas

Everywhere

The Clarke Center's funding model, with its reliance on powerful corporate donors who actively shape global geopolitics, stands in sharp contrast to the crowdfunding model that Abramović relied on to fund the MAI. On the morning of May 7, 2012, approximately two years after her monumental durational piece, "The Artist is Present" came to a close at New York's Museum of Modern Art, Abramović stood before a crowd assembled at the Marina Abramović Breakfast hosted at MoMA PS1 in Long Island City, and presented the MAl's first official architectural designs to the public. Abramović had purchased a 23000-square-foot building located on Columbia Street in Hudson, New York, at the site of a former community theatre built in 1929 and purchased in 2007 (Navarro 2012). To transform the building's physical structure, Abramović retained the services of Rem Koolhaas and Shohei Shigematsu, worldrenowned architects from the design firm Office for Metropolitan 
Architecture (OMA) who embarked on an ambitious redesign for the MAI (Navarro 2012). The firm's detailed visual renderings and scale model of the proposed renovations lent the weight of materiality to Abramović's institutional vision. At the PS1 breakfast, guests were even invited to put their heads through a hole in the center of the model to enter the building quite literally and explore the chambers located around its perimeter.

The extraordinary level of detail we have about this non-existent institute comes from an explosion of speculative artworks-rendered through a variety of digital and print media-determined to foresee what the institute might look and how it might function. In addition to OMA's three-dimensional architectural model and its set of artistic renderings of the MAl, other speculative art that imagined the Institute's future included a YouTube video in which Lady Gaga demonstrates the Abramović Method, a presentation at the Harvard Graduate School of Design, a TED talk, a video game, a virtual tour, a website, and even a physical address on the latest version of Google Maps. In addition, countless newspaper and magazine profiles detailed what Abramović's state-of-the-art performing arts institute of the future would offer.

However, some of the most powerful narrative accounts of the MAI were written for Kickstarter. Even before Robinson's fictionalization, Abramović's team wrote and posted stories that brought the MAI to life on the Kickstarter site in 2013 as they began seeking donations from the public in order to pay for an initial \$600,000 in planning expenses. Kickstarter describes itself as "a funding platform for creative projects" (Pereira), and soliciting narrative-specifically speculative narrative that describes imagined futures for hopeful artists-is an explicit component of its fundraising method. In fact, its site encourages users to attract pledges by mastering the art of "Telling your story." "Imagine explaining your project to a friend," the site implores new users: "What would you say? What might they ask you? And how would you show them you're serious, prepared, and capable of doing a great job? Your project page is your chance to tell people that story: who you are, what you want to make, and why" ("Telling Your Story"). The site even offers users an online "course on strategic storytelling" ("Telling Your Story"). By enrolling in the webinar, 
the host promises, "[y] ou'll figure out how to tell a story in a way that will get people excited about what it is you're doing" (Pereira). In their explicit solicitation of stories then, online crowdfunding platforms have emerged as privatized literary institutions that catalyze what we might think of as short form speculative fiction shot through with the demand to perform neoliberal subjecthood. Narratives extolling what one could accomplish-if only one had the financial means-are a byproduct of the turn to support art making through private corporate sites. Kickstarter effectively grooms its customers to become amateur speculative fiction writers who market personal narratives brimming with entrepreneurial optimism in exchange for a shot at crowdfunded futures.

In addition to the narrative arts, Abramovićs team turned to the performing arts to procure funding from potential contributors. MAl's Kickstarter page proposes that a contributor's buy-in be at once financial and civic:

Why Kickstarter? We aim to create a global community of collaborators and want you to be part of it. By inviting the broader public to contribute to our early development, Kickstarter helps to affirm and build the engaged community necessary to sustain MAl into the future. We have designed rewards that encourage backers to engage with time-based and immaterial works. With your contribution, you become a founder of the institute not only financially, but also conceptually, by partaking in the very experiences we hope to create. ("Marina Abramović Institute")

One World

The Americas

Everywhere

The "experiences" offered by the MAI varied depending on the amount "collaborators" pledged. For example, for one dollar, collaborators could receive "a hug from Marina Abramović"; for twenty-five dollars, collaborators could perform an Abramović Method exercise such as slow motion walking, eye gazing, or water drinking simultaneously with Abramović and other backers online, effectively "creating a large public performance that occurs at the same time in different locations all over the world" ("Marina Abramović Institute"). As the sly slippage from contributor to collaborator implies, what is perhaps most striking about the MAl's capital campaign is how it readily reframes financial contributions mediated through a private company as a collective gesture 
patrons must perform to access Abramovićs vision of a civically engaged global public.

This use of Kickstarter to reframe arts institute funding as a form of community engagement exemplifies what scholar Rodrigo Davies has called civic crowdfunding, that is "the use of crowdfunding for projects that produce community or quasipublic assets" (2015: 342). "Crowdfunding," Davies notes, "is often framed by platform owners and project sponsors as an opportunity to participate: inviting backers to take a role in the creation of a product or project, a way to join a movement of like-minded people and a way to bring into being something that might otherwise have not existed" (344). From this vantage, it is not surprising that framing crowdfunding as civic participation dovetails with performance studies' conventional notions of vanguard performance art. Such performance is viewed as an art that "engages, empowers, activates, and makes the spectator aware of individual liberties, activist potential, and spectatorial agency," according to scholar Kimberly Jannarone (2015).

The MAl's approach to crowdfunding all but ensures that potential contributors experience their financial contribution through the Kickstarter platform as the cost of admission into the sort of 'engaged community' it promises will come into being through collective, embodied performance. This is in keeping with Abramović's previous claims that performance art is uniquely positioned to transform the social forms of the future because it connects small-scale personal action to large scale social transformation. In interviews, she has articulated the link between durational performance art pieces that involve the public-such as The Abramovic Method-and speculative world building: "Our lives are so fast," she states, "Art must slow us down. These exercises are based on repetition. Something small, a ritual, eventually becomes a universe" (Gibson 2015). In the summer before her residency at the Clarke Center, for example, Abramović led a durational public performance piece in which participants described how "facilitators worked at transforming ordinary tasks by performing them slowly" so much so that "the slowness emptied the prescribed actions of utility" (Balkin and D'Urso 2017: 96). As architectural theorist Sanford Kwinter, who moderated Abramović's “Designing 
an Institute for Performance Art" presentation at the Harvard Graduate School of Design, put it: the MAl's "principle mandate" was "giv[ing] place to disciplined forms of space-and-time-altering experience, to alter the bodies and minds of the users themselves." ("Designing an Institute for Performance Art"). While Abramović hasn't discussed her art explicitly in terms of political economy, slowing down human bodies, rendering them useless to programs of productivity would seem to issue a provocative challenge to the tempo of capitalism.

And yet, given that Abramović's potential communal initiative was funded through Kickstarter, the MAl also provokes concerns raised by Davies, namely that privatizing "civic crowdfunding is shrinking government [...] by providing replacement public services, or by creating new services that did not previously exist or were outside the capability of government" (Davies 2015: 350). Indeed, the Trump Administration's proposed outsourcing of arts funding to Kickstarter's marketplace of ideas confirms such concerns are well founded. At Hudson's municipal level, the Institute's privatized funding scheme raised questions concerning what community the fundraising project ultimately seeks to serve. While Abramovic has noted that OMA's architects were interested in the local community-"they're talking about infrastructures. They're talking about society. They're thinking about master plan. How this building can function in the Hudson itself" states that "Abramović was inspired by the general public's desire

One World

The Americas

Everywhere to engage with immaterial works," a reference not to the Hudson community in particular but rather to the cosmopolitan audience who attended "The Artist is Present" in New York City (Cascone 2017).

Despite the fact that Abramovic ultimately failed to procure sufficient funding for the completion of MAl Hudson and officially abandoned the project in late 2017, the trace of the idea of an arts institute nonetheless provokes questions of formal classification for contemporary literary scholars. To be sure, there is a long history of literary criticism linking literary form to arts funding schemes. ${ }^{5}$ Writing of the Kiva funding model, for example, literary scholar Dan Sinykin has pointed out that in our own moment, "contemporary

\footnotetext{
4. See "Designing an Institute for Performance Art."

5. See for example, Doherty (79-101), and Donofrio (100-128).
} 
writing is inextricable from the vast yet barely visible financial networks that structure the present" (Sinykin 2017: 203). The linkage between textual artifact and funding scheme is made newly visible in Kim Stanley Robinson's novel New York 2140 since the global networks of patronage forged by Kickstarter and marshaled to fund the MAI appeared reliable enough for Robinson to place the then-prospective Institute securely in what he considered to be 2140's world of historical realism. And yet, the fact that the money to build MAI Hudson ultimately was not raised through these channels means that a fictional institute now occupies real estate in the novel's historical-realist universe. Its presence not only complicates Robinsons's stated generic commitments to science fiction as historical literature, but also asks us to reassess whether the speculative futurities churned out by privatized crowdfunding platforms such as Kickstarter can be relied upon to build real futures for the arts. 
WORKS CITED

"3015," Sheldon Brown. http://sheldon-brown.net/3015/ Accessed 23 Dec. 2018.

A Budget for a Better America: Fiscal Year 2020, Budget of the US Government. US Government Publishing Office, Washington, DC, 2019.

"About Viasat." https://www.viasat.com/about. Accessed 11 Jun. 2019.

"About Clarion." http://clarion.ucsd.edu/about-clarion. Accessed 11 Jun. 2019.

Arthur C. Clarke Center for Human Imagination. http://imagination.ucsd. edu. Accessed 11 Jun. 2019.

"Arthur C. Clarke. Biography." The Arthur C. Clarke Foundation. http://www. clarkefoundation.org/arthur-c-clarke-biography/. Accessed 11 Jun. 2019.

Balkin, Sarah and Sanda D'Urso. "'My Relationship to the Public is Changing,' Marina Abramović In Residence." TDR: The Drama Review vol. 61, no. 3, 2017, pp. 94-111.

Cascone, Sarah. "'The Artist is Present but the Money Isn't' Marina Abramović Scraps \$31 Million Performance Art Facility." Artnet's News, Oct. 6, 2017. https://news.artnet.com/art-world/marinaabramovic-cancels-planned-rem-koolhaus-building-1108310. Accessed 20 Dec. 2020

"Clarion Distinguished Alumni \& Faculty." http://clarion.ucsd.edu/clarionsdistinguished-alumni-faculty. Accessed 11 Jun. 2019.

One World The Americas Everywhere

"Clarion Workshop: The Clarion Science Fiction and Fantasy Writers' Workshop" http://clarion.ucsd.edu. Accessed 11 Jun. 2019.

Davies, Rodrigo. "Three provocations for civic crowdfunding." Information, Communication o Society, vol. 18, no. 3, 2015. pp. 342-355, DOI: 10.1080/1369118X.2014.989878.

"Designing an Institute for Performance Art," Lecture. Marina Abramović Institute. oma.eu. Harvard University, Cambridge. 4 Mar. 2013.

Doherty, Margaret. "State-Funded Fiction: Minimalism, National Memory, and the Return to Realism in the Post-Postmodern Age." American Literary History vol. 27, no. 1, 2014, pp. 79-101.

Donofrio, Nicholas. "Multiculturalism, Inc.: Regulating and Deregulating the Culture Industries with Ishmael Reed." American Literary History, vol. 29 no. 1, 2017, pp. 100-128. 
"Episode 3: The Hard Problem." Arthur C. Clarke Center for Human Imagination, http://imagination.ucsd.edu. Accessed 23 Dec. 2018.

Gibson, Prudence. "The Mystical Stillness of Marina Abramović in Sydney." The Conversation, June 24, 2015. https://theconversation.com/ the-mystical-stillness-of-marina-abramovic-in-sydney-43640. Accessed 23 Dec. 2018.

Heise, Ursula and Kim Stanley Robinson. "Realism, Modernism, and the Future: An Interview with Kim Stanley Robinson." ASAP/ Journal, vol. 1, no. 1, 2016.

Imagination. http://imagination.ucsd.edu/about. Accessed 11 Jun. 2019.

Jannarone, Kimberly. "The Political Fallacy of Vanguard Performance," Vanguard Performance Beyond Left and Right. U of Michigan Press, 2015, pp. 1-15.

Kornbluh, Anna. "Climate Realism, Capitalist, and Otherwise." Mediations, vol. 33, no. 1-2, 2020, pp. 99-118.

"Marina Abramović Institute," Kickstarter. https://www.kickstarter.com/ projects/maihudson/marina-abramovic-institute-the-founders. Accessed 20 Dec. 2020.

Navarro, Pedro. "OMA and New Marina Abramović Institute for the Preservation of Performance Art (MAI)." Metalocus. https://metalocus. es. August 5, 2012. Accessed 23 Dec. 2018.

Pereira, Stephanie, "Storytelling Basics: How Creatives and Brands Can Build a Following. Learn with Kickstarter." Skillshare. https://www. skillshare.com/site/join?teacherRef=7421477\&via=teacher-referral-partner\&utm_source=kickstarter\&utm_medium=teacherreferral-partner\&utm_campaign=kickstarter-site\&type=Que stion\&category=business\&t=Strategic-Storytelling-BuildingCommunity-Around-Your-Creative-Project\&sku=1437389406. Accessed 23 Dec. 2020.

Robinson, Kim Stanley. New York 2140. Orbit, 2017.

Sinykin, Dan. "Microfinance Lit: Jhumpa Lahiri's "Sexy," the Grameen Bank, and Kiva." Genre: Forms of Discourse and Culture, vol. 50. no. 2, 2017, pp. 201-217. DOl: https://doi.org/10.1215/00166928-3890037.

"Telling Your Story." Kickstarter. https://www.kickstarter.com/help/handbook/your_story. Accessed 20 Dec. 2020. 
